\title{
Pengaruh Kontrol Sosial terhadap Perilaku Bullying
}

\author{
Bibit Kurniati \\ Universitas Kristen Satya Wacana, Salatiga \\ Email: 292015099@student.uksw.edu
}

\begin{abstract}
Currently, bullying behavior often occurs among students. Many studies know the causes of bullying behavior that occurs among learners. The purpose of this paper is to determine the effect of social control on bullying behavior that occurs among students. Which later the behavior can be prevented or reduced. In this case, social control also affects the actions of the students. In addition, the parents and teachers must also supervise and control the activities or activities undertaken by students, so that later action of bullying that does not occur among students.
\end{abstract}

Keywords: Control Social, Bullying

Licensees may copy, distribute, display and perform the work and make derivative works and remixes based on it only if they give the author or licensor the credits (attribution) in the manner specified by these. Licensees may copy, distribute, display, and perform the work and make derivative works and remixes based on it only for non-commercial purposes.

\section{PENDAHULUAN}

Dalam artikel ini membahas sedikit mengenai pengaruh kontrol sosial terhadap perilaku bully, agar nantinya tidak ada lagi aksi bully yang terjadi di kalangan pelajar, agar generasi Indonesia memiliki jiwa sosial dan memiliki akhlak mulia. Penelitian mengenai bullying di sekolah semakin meningkat di luar negeri akhir-akhir ini (Sari \& Azwar, 2017). Menurut data KPAI 87,6 persen anak mengaku pernah mengalami kekerasan di lingkungan sekolah dalam berbagai bentuk. Dari angka 87,6 persen tersebut, sebanyak 29,9 persen kekerasan dilakukan oleh guru, 42,1 persen dilakukan oleh teman sekelas, dan 28,0 persen dilakukan oleh teman lain kelas (Winurini, 2015). Dari kekerasan tersebut kita tahu bahwa disebabkan oleh banyak faktor yang memengaruhi, sehingga menimbulkan perlaku bullying yang terjadi di kalangan antar pelajar atau guru dengan pelajar. Sehingga dari kejadian itu tahu bahwa perilaku bullying yang terjadi di Indonesia semakin meningkat.

Undang-undang Nomor 20 tahun 2003 pasal 1 ayat (1) menyebutkan bahwa
"Pendidikan adalah usaha sadar dan terencana untuk mewujudkan suasana belajar dan proses pembelajaran agar peserta didik secara aktif mengembangkan potensi dirinya untuk memiliki kekuatan spiritual keagamaan, pengendalian diri, kepribadian, kecerdasan, akhlak mulia, serta keterampilan yang diperlukan dirinya, masyarakat, bangsa dan negara" (Presiden Republik Indonesia, 2003). Guna mencapai tujuan tersebut, diperlukan kondisi belajar yang kondusif dan jauh dari kekerasan. Dari pernyataan tersebut, maka dapat disimpulkan bahwa Pendidikan merupakan hal penting bagi kehidupan manusia. Dengan kata lain pendidikan merupakan suatu cara pokok manusia agar dapat mengembangkan potensi yang ada dalam dirinya yang nantinya dapat berguna bagi mereka sendiri, orang lain, bangsa dan negara.

Kekerasan bullying di sekolah juga terjadi di Indonesia, salah satunya ialah tindakan seorang siswa kelas II meregang nyawa, diduga siswa tersebut berkelahi dengan temannya sekitar pukul 07.00 pagi saat berangkat sekolah anak tersrbut bersekolah di SDN Longkewang, Desa Hegarmanah, 
Kecamatan Cicantayan, Kabupaten Sukabumi, Jawa Barat.

Bullying dapat dilakukan secara verbal, psikologis dan fisik (Zakiyah, Humaedi, \& Santoso, 2017). Bentuk perilaku tersebut dikatakan sebagai salah satu bentuk delinkuensi (kenakalan anak), karena perilaku tersebut melanggar norma masyarakat, dan dapat dikenai hukuman oleh lembaga hukum (Sumara, Humaeadi, \& Santoso, 2017). Menurut penelitian Peterson dan Rigby di Australia, bullying yang biasanya terjadi di sekolah, mulai meningkat pada awal secondary school atau setingkat dengan SMP (Sekolah Menengah Pertama) (Khoirunnisa, 2015). Aksi bully saat ini tidak hanya bertindak pada perlakuan fisik saja namun, juga bisa berlaku pada mental anak, sehingga cenderung anak yang mengalami akasi bullying ini memiliki trauma psikis yang dalam.

Sejumlah penelitian menunjukkan bahwa kontrol sosial turut memengaruhi dalam aksi bully tersebut yang terjadi di sekitar kita. Dalam hal ini kontrol sosial bertujuan untuk mencegah adanya aksi bully yang saat ini marak terjadi di kalangan anak ataupun remaja, karena dalam hal ini mereka dalam tahap mencari jati diri dan mementingkan ego masing-masing. Namun di samping itu perilaku bullying tidak hanya terjadi karena dari pengaruh lingkungan, namun juga bisa dari diri masing-masing yang belum bisa mengontrol dirinya.

Saat ini sering terjadi aksi bully di kalangan pelajar, hal itu dipicu oleh masalah internal, misalnya kekurangan yang dimiliki salah satu siswa. Dalam hal ini kekurangan dalam hal keterbatasan mental, seringkali siswa yang mempunyai mental yang kuat akan marendahkan siswa yang mempunyai mental lebih rendah. Oleh karena itu hal ini menyebabkan aksi bully yang terjadi kalangan pelajar. Masalahnya-masalah tersebut antara lain apakah control sosial memengaruhi aksi bully yang kerap terjadi di lingkungan sekolah.

Setelah mengkaji masalah di atas, tujuan tersebut adalah untuk mengurangi ataupun menghilangkan adanya aksi bully yang saat ini kerap terjadi di kalangan pelajar. Dengan harapan melalui kontrol sosial dapat mencegah aksi tersebut. Menjadikan generasi
Indonesia yang memiliki jiwa sosial tinggi, dan berakhlak mulia.

\section{HASIL PENELITIAN DAN PEMBAHASAN}

\section{Kontrol Sosial}

Kontrol sosial adalah cara bagimana seseorang dapat menaati peraturan dan norma yang berlaku pada lingkungannya. Selain itu kontrol sosial juga dapat mengarahkan seseorang dalam berperilaku dalam kesehariannya saat berada di lingkungan (Irel, 2017).

Jadi menurutnya kontrol sosial adalah bagaimana seseorang dapat berperilaku sesuai dengan norma dan nilai yang berlaku di lingkungannya, dengan tujuan agar tidak terjadi penyimpangan sosial yang dapat merugikan dirinya maupun orang lain.

Kontrol sosial yaitu segala sesuatu yang mencakup dari proses mendidik, mengajak, atau memaksa banyak orang agar dapat mematuhi aturan-aturan dan nilai sosial yang sedang berlaku di masyarakat. Dengan tujuan agar terciptanya kehidupan sosial yang selaras tanpa adanya konflik (Fitriyaningsih \& Bakhri, 2017).

Jadi kontrol sosial itu merupakan suatu proses di mana proses itu bersifat mendidik bagi masyarakat agar mereka tidak melanggar peraturan atau norma sosial yang berlaku di masyarakat. Dengan tujuan agar dapat terciptanya kehidupan yang selaras dan damai tanpa adanya pertentangan. Khususnya pada kalangan remaja yang saat ini kerap menerima pengaruh dari sumber-sumber mana pun baik itu bersifat positif ataupun bersifat negatif. Sehingga remaja memerlukan adanya peran orang lain untuk dapat mengendalikan dirinya.

Masa usia remaja adalah masa yang rentan dalam fase pertumbuhan dan perkembangan manusia mengungkapkan secara psikologi masa remaja adalah usia saat individu berintegrasi dengan masyarakat dewasa, usia saat anak tidak lagi merasa di bawah tingkat orang yang lebih tua, melainkan berada dalam tingkat yang sama. Masa remaja adalah masa transisi atau peralihan dari masa kanak-kanak menuju dewasa yang ditandai dengan adanya perubahan aspek fisik, psikis \& psikososial (Jannah, 2016). 
Pemuda atau remaja adalah penerus bangsa yang dapat membuat pembangunan pada suatu negara. Oleh karena itu remaja harus mempunyai kepribadian yang jujur dan bertanggung jawab. Agar nantinya dapat terwujudnya suatu negara yang memiliki pemuda yang berjiwa pemimpin patriotisme, dan mempunyai sehat jasmani dan rohani.

Terdapat banyak faktor yang menyebabkan siswa yang melakukan tindakan bullying, baik dari faktor internal maupun eksternal. Salah satu sebab siswa melakukan bullying yaitu rendahnya kontrol diri pada siswa. Individu dengan kontrol diri yang rendah memiliki kecenderungan menjadi impulsif, senang melakukan perbuatan yang berisiko, dan berpikiran sempit. Menurut Chaplin dalam Titisari (2017) kontrol diri adalah kemampuan untuk menekan atau merintangi tingkah laku impulsif. Pada dasarnya, setiap individu memiliki suatu mekanisme yang dapat membantu mengatur dan mengarahkan perilaku yang disebut kontrol diri.

Sejumlah penelitian yang dilakukan oleh Morton (1999), Jenkins (1995) Cunningham (2007) Yoneyama \& Naito 2003, dan Ma (2001) juga memperlihatkan bahwa bullying di sekolah merupakan masalah perilaku seorang pelajar yang dipengaruhi oleh kontrol sosial pelajar dengan lingkungan sekolahnya, seperti interaksi dengan guru, interaksi dengan teman-teman sebayanya, ketaatan pada peraturan dan norma, metode pendisiplinan dan iklim pada sekolah tersebut. Hal itu terjadi karena siswa sendiri belum bisa mengendalikan dirinya sendiri, yang cenderung memikirkan egonya sendiri tanpa memikirkan efek dari perilaku yang diperbuatnya. Selain itu juga dari pihak sekolah ataupun orang tua kurang memperhatikan kegiatan keseharian anaknya sehingga dari pergaulan tersebut anak mendapatkan efek yang tidak baik dan dapat menimbulkan persoalan yang nantinya akan berpengaruh pada sikap dan perilaku anak tersebut. Namun di samping itu juga tergantung pada masing-masing atau individu dalam mengontrol dirinya terutama dalam pergaulan dengan teman sebaya atau dengan lingkungannya.

Kontrol sosial orang tua pada anak sangatlah penting bagi remaja untuk mengarahkan, memberikan nasehat, memberikan pujian atau hukuman atas perilaku remaja itu sendiri. Saat ini banyak orang tua yang kurang mengontrol pergaulan dan perilaku remaja. Sehingga terjadi kebimbangan dan keraguan remaja mengenai apa yang boleh dilakukan dan apa yang tidak boleh mereka lakukan. Selain itu peran dari lingkungan sekitar juga perlu untuk mengarahkan dan mengawasi remaja tersebut dalam kesehariannya. Dengan tujuan agar nantinya dapat meminimalisir adanya perilaku menyimpang. Selain dari kontrol sosial untuk dapat mengurangi tindakan bullying yang saat ini kerap terjadi, juga perlu adanya kontrol diri dari masing-masing individu menurut Colhum \& Acocella dalam Purwasih, Dharmayana, \& Sulian (2017) mendefinisikan kontrol diri adalah pengaruh seseorang terhadap, dan tentang peraturan, fisiknya, tingkah laku dan proses-proses psikologisnya. Kemudian Avveril dalam Harahap (2017) mendefinisikan kontrol diri sebagai variabel psikologis yang mencakup individu untuk memodifikasi perilaku, kemampuan individu mengelola informasi yang tidak diinginkan, dan kemampuan individu untuk memilih suatu tindakan yang diyakini.

Jadi kontrol diri adalah cara seseorang dapat mengendalikan dirinya dalam bertingkah laku, ucapan, dan tindakan yang harus disesuaikan dengan nilai dan norma yang berlaku di lingkungan. Sehingga dari apa yang dilakukannya akan mendapat hasil atau efek yang positif baik untuk diri sendiri ataupun untuk orang lain.

Aspek dari kontrol diri ini terdiri dari, kemampuan mengontrol perilaku, kemampuan mengontrol stimulus, kemampuan mengontrol suatu peristiwa atau kejadian, kemampuan menafsirkan peristiwa atau kejadian dan kemampuan mengambil keputusan (Harahap, 2017)

\section{Perilaku Bullying}

Bullying adalah perilaku yang disadari dan disengaja dengan tujuan pelaku dapat melukai atau membuat rasa ketakutan pada korban melalui ancaman atau kekerasan berupa pukulan, taendangan dll. Perilaku tersebut dapat membuat pelaku mendapat resiko dikeluarkan dari sekolah (Sari \& Azwar, 
2017a). Selain itu perilaku bullying yang terjadi di sekolah juga berdampak buruk bagi para pelajar, baik yang terjadi pada korban ataupun pada pelaku apabila hal tersebut dilakukan terus-menerus dan tanpa henti (Coloroso, 2007).

Jadi perilaku bullying merupakan suatu tindakan yang berupa ancaman, teror, ataupun melukai seseorang yang nantinya akan berdampak buruk bagi korban karena telah dirugikan, sedangkan dari pihak pelaku mendapatkan hukuman nantinya. Bullying tersebut juga dapat menjadikan seseorang memiliki kecenderungan untuk hidup menyendiri karena takut dengan ancaman atau teror yang nantinya akan menimpanya kembali.

Berdasarkan penelitian di atas, penelitian ini ingin melihat kontrol sosial sekolah terhadap perilaku bullying pelajar dengan perbedaan iklim sekolah berdasarkan kualitas standar sekolah. Dengan kata lain, aksi bully ini merupakan aksi yang dapat merugikan banyak pihak dan berdampak buruk baik pelaku maupun korban. Selain itu juga tergantung dari kualitas atau peran dari sekolah dalam mengarahkan atau mendidik siswanya saat berada di sekolah. Baik dalam perkataan ataupun perbuatan siswa, misalnya dengan memberikan pelajaran PKn yang di dalamnya terdapat pelajaran-pelajaran tentang budi pekerti dan perilaku yang baik dilakukan dan yang tidak baik jika dilakukan, dengan begitu siswa mempunyai gambaran dari apa yang sudah diperoleh dari mengikuti pembelajaran yang nantinya dapat diterapkan dan diamalkan dalam kehidupan nyata.

Menurut Storey dalam Zakiyah et al., (2017), Selain itu bullying juga dapat didefinisikan sebagai suatu bentuk emosional dan fisik yang mempunyai 3 ciri-ciri yaitu delibrate, yaitu perilaku seorang pelaku bullying cenderung menyakiti seseorang atau korban. Sedangkan repeated yaitu pelaku bullying seringkali memilih korban yang cenderung rentan untuk dibully yang sering dianggapnya mempunyai kelemahan. Power imbalance pelaku bullying memilih korban yang dianggapnya rentan. Jadi bullying yang dimaksud adalah kekerasan yang dilakukan oleh pelaku kepada korban baik kekerasan fisik atau mental yang dapat menyebabkan kerugian bagi korban bullying

Bullying adalah sebagai perilaku agresif yang dilakukan berulang-ulang oleh seseorang atau kelompok siswa yang mereka anggap memiliki kekuasaan terhadap orang lain atau siswa lain yang dianggapnya lebih lemah hal tersebut dilakukan dengan tujuan menyakiti orang lain.

Menurut Riauskina dalam Zakiyah et al. (2017) bullying yang ada di sekolah dapat didefinisikan sebagai perilaku hiperaktif yang dilakukan oleh seorang siswa secara berulangulang yang memiliki kekuasaan terhadap siswa lain yang memiliki kelemahan. Dengan kata lain perilaku bullying sering terjadi di sekolahsekolah, dalam hal ini yang sering menjadi target bullying adalah anak-anak yeng memiliki kelemahan atau kekurangan sehingga dari hal tersebut dari pelaku lebih mudah untuk melakukan aksi bullying tersebut.

Jenis bullying sendiri dapat dikelompokkan menjadi 3 kategori antara lain, bullying fisik, yaitu meliputi tindakan menendang, menampar, menjegal, melempar dengan barang dan lain-lain. Bullying verbal, perilaku ini dapat dirasakan oleh indera pendengaran, seperti menghina, memaki, meneriaki, memalukan di depan umum dan lain-lain. dan yang terakhir adalah bullying mental atau psikologis, perilaku ini sangat berbahaya karena dilakukan secara diam-diam dan tidak diketahui oleh korban, misalnya pelaku memandang sinis, merendahkan, melototi, mencibir, dan lain-lain (Satalina, 2014).

Dari ke tiga jenis bullying tersebut, saat ini sering dilakukan anak-anak untuk membully temannya sendiri. Oleh karena itu dari perilaku bullying tersebut sering kali dapat menyebabkan korban dari perilaku tersebut mengalami ganguan baik gangguan fisik ataupun mental. Sehingga dapat merugikan pihak yang terkait baik korban yang mengalami kerugian fisik atau mental, sedangkan untuk pelaku dapat dikenai ancaman hukuman.

Sedangkan menurut Bauman dalam Saifullah (2016) tipe-tipe bullying adalah sebagai berikut:

1. Overt bullying (tindakan bullying terbuka), meliputi perilaku bullying secara fisik dan 
vebal misalnya, mendorong korban hingga jatuh, mengejek dengan tujuan menyakiti, memberi julukan nama, dan lain-lain. Tindakan ini sering dilakukan oleh anak apabila seseorang mempunyai masalah ataupun dendam yang nantinya akan berimbas pada perilaku bullying. Hal ini terjadi apabila tidak ada pengawasan dari lingkungan sekitar baik dari lingkungan keluarga, sekolah atupun lingkungan masyarakat.

2. Indirect bullying (Intimidasi tidak langsung) antara lain agresi relasional, di mana bahaya yang dimunculkan oleh pelaku bullying yaitu dengan cara menghancurkan hubungan-hubungan yang dijalin oleh korban, di antaranya adalah upaya pengucilan, menyebarkan gosip, dan meminta pujian atau suatu tindakan tertentu dari kompensasi persahabatan. Bullying dengan cara tidak langsung sering dianggap tidak terlalu berbahaya jika dibandingkan dengan bullying secara fisik, dinamakan sebagai cara bercanda antar teman saja. Padahal relational bullying lebih kuat terkait dengan stress emosional daripada bullying secara fisik. Bullying secara fisik akan semakin berkurang ketika siswa menjadi lebih dewasa tetapi bullying yang sifatnya merusak hubungan akan terus terjadi sampai usia remaja. Hal ini terjadi apabila seseorang mempunyai masalah dengan orang lain ataupun mempunyai kebencian yang tidak dapat dihilangkan, sehingga untuk melampiaskan mereka biasanya menyebarkan gossip atau kabar berita yang nantinya akan merugikan korban yang akan mendapat malu dari gossip terkait dengannya, sedangkan untuk pelaku nantinya akan mendapat hinaan ataupun cacian dari berita yang sudah di sebarkan apabila itu tidak terbukti benar.

3. c. Cyberbullying (tindakan bullying melalui dunia maya), seiring dengan perkembangan di bidang teknologi, siswa memiliki media baru untuk melakukan bullying yaitu dengan melalui dunia maya, seperti melalui sms, telepon maupun internet. Cyberbullying melibatkan penggunaan teknologi informasi dan komunikasi, seperti $e$-mail, telepon seluler dan peger, sms, website pribadi yang menghancurkan reputasi seseorang, survei di website pribadi yang merusak reputasi orang lain, yang dimaksudkan adalah untuk mendukung perilaku menyerang seseorang atau sekelompok orang, yang ditujukan untuk menyakiti orang lain, secara berulang-ulang kali. Biasanya yang melakukan hal ini mempunyai masalah individu dengan individu sehingga untuk melampiaskan amarahnya seseorang melakukan perilaku bullying ini dengan perantara salah satunya dengan SMS agar orang lain tidak tahu, namun di samping itu apabila hal tersebut dilakukan di sosial media maka perilaku tersebut akan diketahui oleh banyak pihak, perilaku tersebut juga bisa berakibat pada hukuman yang akan berimbas pada tindak pidana bagi kedua belah pihak baik pelaku atau korban.

Dari kasus bullying yang sering terjadi terdapat beberapa faktor yang memengaruhi antara lain) yaitu perbedaan kelas (senioritas), ekonomi, agama, jender, etnisitas atau rasisme, yakni pada dasarnya, perbedaan (terlebih jika perbedaan tersebut bersifat ekstrim) individu dengan suatu kelompok di mana ia bergabung, jika tidak dapat disikapi dengan baik oleh anggota kelompok tersebut, dapat menjadi faktor penyebab bullying. Tradisi senioritas yakni senioritas yang salah diartikan dan dijadikan kesempatan atau alasan untuk membully junior terkadang tidak berhenti dalam suatu periode saja. Hal ini tak jarang menjadi peraturan tak tertulis yang diwariskan secara turun temurun kepada tingkatan berikutnya. Keluarga yang tidak rukun yakni kompleksitas masalah keluarga seperti ketidakhadiran ayah, ibu menderita depresi, kurangnya komunikasi antara orang tua dan anak, perceraian atau ketidakharmonisan orang tua dan ketidakmampuan sosial ekonomi merupakan penyebab tindakan agresi yang signifikan. Dari faktor tesebut biasanya dilatarbelakangi oleh masalah pribadi yang nantinya disangkutpautkan dengan masalah senioritas dan junioritas. Hal tersebut bisa menyebabkan perilaku bullying terjadi yang dapat merugikan orang lain (Sufriani \& Sari, 2017a)

Selain itu, selama ini faktor penyebab perilaku kenakalan selalu dikaji dari sisi eksternal individu. Banyak teori yang 
menganggap bahwa perilaku menyimpang, terutama kejahatan, adalah hasil belajar individu dari lingkungan atau akibat tekanan dari suatu keadaan tertentu. Denson, DeWall, \& Finkel (2012) menyatakan bahwa kebanyakan teori dan jurnal yang berkaitan dengan agresi maupun perilaku delinkuen mengabaikan faktor internal dari dalam diri. Ketika adanya dorongan seseorang untuk berbuat menyimpang maupun agresi sedang mencapai puncaknya, hal kontrol diri dapat membantu individu menurunkan agresi dengan mempertimbangkan aspek aturan dan norma sosial yang berlaku.

Faktor internal lainnya yaitu kepercayaan diri yang berhubungan dengan perilaku bullying. Hervita dalam Putri, Nauli, \& Novayelinda (2015) menyatakan bahwa percaya diri ialah suatu sikap atau perasaan yakin akan kemampuan diri sendiri sehingga orang yang bersangkutan tidak merasa cemas dalam bertindak, merasa bebas, tidak malu dan tertahan serta mampu bertanggung jawab atas perbuatannya.

Sedangkan faktor eksternal yang berhubungan dengan perilaku bullying yaitu iklim sekolah. Monrad dalam Mutiara \& Sobandi (2018) mengungkapkan adapun aspek-aspek iklim sekolah meliputi lingkungan belajar, lingkungan fisik dan sosial, hubungan antara rumah dan sekolah, dan keamanan sekolah. Lingkungan sekolah yang bersih, manajemen atau perilaku yang baik yang tercipta di dalam maupun di luar kelas serta hubungan interpersonal antara guru dan siswa yang baik akan menciptakan suasana atau iklim sekolah baik (Hadiyanto, 2016).

Hal ini sering terjadi apabila anak kurang mendapatkan perhatian dari orang terdekatnya, sehingga anak tersebut melampiaskannya kepada korban bullying. Selain itu yang terjadi di sekolah juga dari tingkatan tinggi rendahnya suatu jabatan atau sering disebut senior dan junior, hal inilah yang seringkali menjadi faktor dari perilaku bullying. Selain itu juga kesetaraan jender juga dapat menyebabkan perilaku bullying itu terjadi karena adanya perbedaan laki-laki dan perempuan yang terletak pada stereotip maskulin dan feminis yang sudah terbangun dalam masarakat (Abbott, 1992).
Siswa yang mempunyai kecenderungan sebagai pelaku bullying pada umumnya memiliki karakteristik sebagai berikut: (a) suka mendominasi anak lain, (b) suka memanfaatkan anak lain untuk mendapatkan apa yang diinginkan, (c) sulit melihat situasi dari titik pandang anak lain. Dalam hal ini pelaku tersebut hanya memikirkan apa ada dipikirannya tersebut (Coloroso, 2007). Tanpa memandang dan melihat korban yang nantinya akan menjadi target untuk diperlakukan semena-mena.

Sedangkansiswa yang akan dijadikan atau menjadi korban bullying biasanya memiliki karakteristik sebagai berikut: (a) anak baru di lingkungan itu, (b) anak termuda atau paling kecil di sekolah, (c) anak yang pernah mengalami trauma sehingga sering menghindar karena rasa takut (Coloroso, 2007). Dari ciri tersebut dapat disimpulkan bahwa anak yang menjadi korban bullying itu merupakan anak yang dianggapnya berbeda dari teman lainnya, sehingga dari perbedaan yang dimilikinya bisa membuat orang lain merasa tidak suka atau tidak berkenan untuk bergaul bersamanya.

Selain itu menurut Duane Alexander, M.D., Direktur Institut Nasional Kesehatan Anak dan Perkembangan Manusia di Amerika menjelaskan tahun 2001 bullying adalah masalah kesehatan publik yang patut mendapatkan perhatian (Nusantara, 2008). Orang-orang yang menjadi korban bullying semasa kecil akan mengalami depresi dan kurang percaya diri di masa dewasa. Sementara itu tindak pelaku bullying akan melakukan hal tersebut di kemudian hari. Tindakan bullying tersebut tidak semata-mata hanya diperhatikan, namun juga diatasi dan dituntaskan khususnya kasus yang terjadi di kalangan pelajar di Indonesia. Tidak hanya itu saja saat ini juga kasus bullying juga sering terjadi pada orang dewasa yang seharusnya memiliki pemikiran yang cukup dewasa.

Perbedaan agresi berdasarkan jender juga terletak pada pergaulannya. Anak laki-laki biasanya didefinisikan orang yang dapat mengambil tindakan berresiko dan bisa terlibat dalam perkelahian dalam kelompok. Sedangkan perempuan seringkali didefinisikan sebagai orang yang mandiri, penuh pertimbangan, yang taat pada peraturan (Saputra, Hanifah, \& Widagdo, (2017). Dalam 
hal ini sering kali perilaku bullying tersebut menimpa pada perempuan, karena dinggapnya bahwa perempuan adalah orang yang lemah dan rentan terkena tindak kekerasan yang saat ini kerap terjadi di kalangan pelajar di Indonesia. Sehingga dari perilaku yang sering menimpanya saat ini perempuan mengantisipasinya dengan mengikuti bela diri untuk dapat melingi diri dari bahaya yang sewaktu-waktu akan menimpanya.

Penelitian yang dilakukan oleh Sufriani \& Sari (2017) juga memperlihatkan bahwa bullying di sekolah merupakan masalah perilaku seorang pelajar yang dipengaruhi oleh kontrol sosial pelajar dengan lingkungan sekolahnya, seperti interaksi dengan guru, interaksi dengan teman-teman sebayanya, ketaatan pada peraturan dan norma, metode pendisiplinan dan iklim pada sekolah tersebut. Hal itu terjadi karena siswa sendiri belum bisa mengendalikan dirinya sendiri, yang cenderung memikirkan egonya sendiri tanpa memikirkan efek dari perilaku yang diperbuatnya. Selain itu juga dari pihak sekolah ataupun orang tua kurang memperhatikan kegiatan keseharian anaknya sehingga dari pergaulan tersebut anak mendapatkan efek yang tidak baik dan dapat menimbulkan persoalan yang nantinya akan berpengaruh pada sikap dan perilaku anak tersebut. Namun di samping itu juga tergantung pada masing-masing atau individu dalam mengontrol dirinya terutama dalam pergaulan dengan teman sebaya atau dengan lingkungannya.

Solusi yang lebih efektif yakni program yang menjadikan sistem sosial sebagai sasaran perubahan, dan bukan hanya berfokus terhadap perubahan individual baik dari sisi pelaku maupun korban bullying. Perlu dipahami bahwa bullying merupakan perilaku instrumental. Tanpa disadari perilaku tersebut telah diberikan reward oleh lingkungan baik reward yang kasat mata seperti barang-barang dan uang yang diberikan korban pada pelaku, ataupun reward tidak kasat mata seperti perasaan dominan, berkuasa, dan ditakuti oleh anak-anak lain yang dianggapnya lebih lemah.

Maka Fithria \& Auli (2016) mengatakan bahwa bullying akan dapat dikurangi secara signifikan apabila sistem tempat di mana bullying tersebut muncul tidak memberikan imbalan apapun, dan justru memberikan "denda" atau hukuman tiap kali perilaku bullying muncul. Salah satu program yang sangat komprehensif yang ditujukan untuk menanggulangi bullying dan terbukti efektif yakni the bully busters program. Fokus dari program ini yakni merubah sistem sosial sehingga kemunculan bullying bisa dihindarkan (Aryuni, 2017). Program tersebut memiliki beberapa prinsip utama sebagai berikut:

Prinsip utama yang pertama yaitu bahwa mengubah lingkungan lebih berdampak kuat daripada merubah individu per individu. Masalah bullying seharusnya dilihat sebagai fungsi interaksi antara dua pihak, maka dalam mengubahnya kedua pihak (pelaku dan korban) harus diubah, dan pola hubungan dan interaksi antara keduanya pun harus pula diubah. Hasil penelitian menunjukkan bahwa dalam rangka mengubah hal ini, pendekatan yang berfokus pada upaya merubah lingkungan sekolah terbukti lebih efektif. Penekanan yang kuat diberikan pada pentingnya upaya meningkatkan kesadaran dan skill para guru dan skill semua siswa di sekolah, terlepas dari apakah mereka korban atau pelaku bullying ataukah mereka bukan pihak yang terlibat secara langsung (Aryuni, 2017). Sejatinya bukan hanya pihak-pihak yang terlibat langsung saja yang terkena dampak bullying, namun seluruh siswa di sekolah tersebut terpengaruh oleh adanya bullying.

Prinsip kedua, yaitu pencegahan lebih baik daripada intervensi. Prinsip ini merupakan prinsip dasar yang selalu dipakai dalam berbagai permasalahan yang terjadi, bagaimana pun pencegahan permasalahan bullying tentu lebih utama dibandingkan melakukan intervensi sesudah terjadinya bullying. Fenomena kekerasan biasanya merupakan suatu serangkaian kejadian. Untuk memahaminya, kita harus menelusuri apa yang menyebabkan munculnya hal tersebut. Dalam rangka upaya pencegahan ini, seluruh komponen sekolah, khususnya guru-guru harus dipahamkan mengenai program pencegahan bullying ini. Semua guru harus dilibatkan dalam program pencegahan bullying ini, sehingga penerapan di masing-masing kelas selaras dalam menggunakan pendekatan anti kekerasan, sehingga dampaknya menjadi lebih 
luas. Program yang komprehensif dan melibatkan seluruh komponen sekolah akan lebih efektif mencegah bullying dan meningkatkan rasa aman di sekolah dibandingkan memfokuskan pada sebagian siswa melalui pendekatan individual. Tentu saja merupakan suatu hal yang lebih baik untuk mencegah bullying melalui mengajak dan mengajarkan para guru dan siswa untuk mengembangkan skill personal dan interpersonal. Selain itu juga terdapat faktor lainnya Secara umum diperoleh bukti empirik bahwa model konseling kognitif perilaku efektif untuk menanggulangi bullying baik pada pelaku, korban baik berdasakan pola asuh maupun latar belakang sekolah. Keefektifan MKKP tersebut dapat dianalisis dari sisi keunggulan konseling kognitif-perilaku. Menurut Dobson (2001) mencatat beberapa kelebihan pendekatan konseling kognitif perilaku bagi populasi anak-anak dalam setting sekolah, sebagai beikut:

1. Prinsip-prinsip KKP mudah dipahami dan dapat diadaptasikan pada anak-anak hampir semua usia dan dari banyak latar belakang kultural.

2. Kelompok KKP cenderung berjangka pendek dan memakai intervensi singkat, yang cocok dalam latar sekolah ketika waktunya terbatas.

3. Konsep-konsep yang mudah diajarkan dapat diterjemahkan untuk memperoleh keterampilan-keterampilan hidup.

4. Anak-anak dan remaja dapat mempelajari kontrol diri emosional melalui upaya memahami hubungan antara pikiran, perasaan, dan perilaku.

5. Kelompok KKP membantu para peserta menangani hal-hal yang dapat mereka ubah dan menerima hal-hal yang tidak dapat mereka ubah.

6. Prinsip-prinsip kognitif membantu memberdayakan anak-anak dan remaja dalam 724 menangani permasalahan saat ini dan mengantisipasi masalah masa depan. (kompetensi sosial) yang lebih efektif dibandingkan melakukan penanggulangan pasca terjadinya kasus bullying.

\section{SIMPULAN DAN SARAN}

\section{Simpulan}

Dari penjelasan di atas dapat disimpulkan bahwa aksi bully yang terjadi saat ini dipengaruhi oleh beberapa hal, salah satunya kurang perhatiannya dari pihak orang tua maupun sekolah. Maka dari itu kontrol sosial sangat berpengaruh dalam aksi bully, karena kontrol sosial yang ada di lingkungan dapat mencegah ataupun mengurangi aksi bully. Hal tersebut dapat dicapai dengan melakukan pendekatan salah satunya yaitu komunikasi dengan anak. Dengan melakukan hal tersebut maka sebagai orang tua atau guru dapat mengetahui apa yang sedang menjadi masalah yang dihadapi oleh siswa atau anaknya. Selain itu dalam menjalin komunikasi dengan anak seharusnya juga mengetahui keadaan fisik atau mental anak, dengan begitu dalam menjalani komunikasi anak tidak dalam keadaan tertekan. Sehingga aksi bully dapat dicegah sedini mungkin agar tidak ada pihak yang dirugikan yaitu korban dan tidak ada pihak yang merugikan orang lain seperti pelaku. Agar hal tersebut tidak terjadi, maka perlu adanya kerjasama dari pihak sekolah, masyarakat, orang tua dan lingkungan sekitar. Dengan begitu akan terciptanya kehidupan yang aman, nyaman dan tidak ada lagi diskriminasi terhadap individu atau kelompok yang saat ini sering disebut dengan istilah bullying.

\section{Saran}

Sebaiknya dari pihak sekolah memberi tindak lanjut dari peristiwa yang terjadi di sekolah, sedangkan untuk orang tua perlu adanya komunikasi dan perhatian kepada anaknya, sehingga tindakan bullying tidak terjadi lagi. Selain itu dari lingkungan masyarakat juga perlu memperhatikan pergaulan yang ada di sekitar lingkungannya sehingga dapat meminimalisir adanya tindakan bullying yang saat ini kerap terjadi.

\section{DAFTAR PUSTAKA}

Abbott, M. R. (1992). Masculine And Feminine: Gender Roles Over The Life Cycle. New York: McGraw-Hill.

Aryuni, M. (2017). Strategi Pencegahan 
Bullying melalui Program "Sekolah Care" bagi Fasilitator Sebaya. Asian Journal of Environment, History and Heritage, 1(September), 211-222.

Coloroso, B. (2007). Stop Bullying: Memutus Rantai Kekerasan Anak dari Prasekolah Hingga SMU. Jakarta: PT Serambi Ilmu Semesta.

Denson, T. F., DeWall, C. N., \& Finkel, E. J. (2012). Self-Control and Aggression. Current Directions in Psychological Science, 21(1), 20-25. https://doi.org/10.1177/096372141142945 1

Dobson, K. (2001). Handbook of CognitiveBehavioral Therapies. New York: The Guilford Press.

Fithria, \& Auli, R. (2016). Faktor-faktor Yang Berhubungan dengan Perilaku Bullying, VII(3), 9-17.

Fitriyaningsih, K., \& Bakhri, S. (2017). Kontrol Sosial dalam Pembinaan Karakter Religius Peserta Didik Muslim di Sekolah Menengah Kejuruan Negeri 1 Dukuhturi Kabupaten Tegal. Sosiologi Reflektif, 12(1), Habituation, Religius Character, Reward and Puni.

Hadiyanto, H. (2016). Teori dan Pengembangan Iklim Kelas \& Iklim Sekolah. Jakarta: Kencana.

Harahap, J. Y. (2017). Hubungan antara Kontrol Diri dengan Ketergantungan Internet di Pustaka Digital Perpustakaan Daerah Medan. Jurnal Edukasi, 3(2), 131-145.

Irel, I. R. (2017). Hubungan Sense of Self dengan Kecenderungan Perilaku Bullying pada Siswa SMA di Jakarta. Psikodimensia, 16(1), 91-106.

Jannah, M. (2016). Remaja dan Tugas-tugas Perkembangannya dalam Islam. Jurnal Psikoislamedia, 1(1), 243-256.

Khoirunnisa, R. (2015). Konsep Diri Remaja Korban Bullying. Jurnal Bimbingan Dan Konseling, 4(10).

Mutiara, N. U., \& Sobandi, A. (2018). Iklim Sekolah sebagai Determinan Minat
Belajar Siswa (School Climate as Determinant Students Learning Interest). Jurnal Pendidikan Manajemen Perkantoran, 3(1), 218-225.

Nusantara, A. (2008). Bullying: Mengatsi Kekerasan di Sekolah \& Lingkungan. Jakarta: Grasindo.

Presiden Republik Indonesia. Undang-Undang Sistem Pendidikan Nasional, Pub. L. No. 20 (2003). Indonesia.

Purwasih, R., Dharmayana, I. W., \& Sulian, I. (2017). Hubungan Kompetensi Kontrol Diri terhadap Kecenderungan Perilaku Agresif Siswa SMK Bengkulu Utara. Jurnal Ilmiah Bimbingan Dan Konseling, 1(1), 52-60.

Putri, H. N., Nauli, F. A., \& Novayelinda, R. (2015). Faktor-faktor yang Berhubungan dengan Perilaku Bullying pada Remaja. JOM, 2(2), 1149-1159.

Saifullah, F. (2016). Hubungan antara Konsep Diri dengan Bullying pada Siswa-siswi SMP (SMP Negerei 16 Samarinda). EJournal Psikologi, 4(2), 200-213.

Saputra, W. N. E., Hanifah, N., \& Widagdo, D. N. (2017). Perbedaan Tingkat Perilaku Agresi Berdasarkan Jenis Kelamin pada Siswa Sekolah Menengah Kejuruan Kota Yogyakarta. Jurnal Kajian Bimbingan Dan Kon, 2, 142-147.

Sari, Y. P., \& Azwar, W. (2017). Fenomena Bullying Siswa: Studi tentang Motif Perilaku Bullying Siswa di SMP Negeri 01 Painan, Sumatera Barat. Ijtimaiyya: Jurnal Pengembangan Masyarakat Islam, 10(2), 333-367.

Satalina, D. (2014). Kecenderungan Perilaku Cyberbullying dtinjau dari Tipe Kepribadian Ekstrovert dan Introvert. Jurnal Ilmiah Psikologi Terapan, 02(02), 294-310.

Sufriani, \& Sari, E. P. (2017a). Faktor yang Mempengaruhi Bullying pada Anak Usia Sekolah di Sekolah Dasar Kecamatan Syiah Kuala Banda Aceh. Idea Nursing Journal, VIII(3).

Sufriani, \& Sari, E. P. (2017b). Faktor yang Mempengaruhi Bullying pada Anak Usia 
Sekolah di Sekolah Dasar Kecamatan Syiah Kuala Banda Aceh. Idea Nursing Journal, VIII(3).

Sumara, D., Humaeadi, S., \& Santoso, M. B. (2017). Kenakalan Remaja dan Penanganannya. Jurnal Penelitian \& PPM, 4(2), 129-389.

Titisari, H. T. D. (2017). Hubungan antara Penyesuaian diri dan Kontrol diri dengan Perilaku Delikuen pada siswa SMA Muhammadiyah 1, Jombang.
Psikodimensia, 16(2), 131-140.

Winurini, S. (2015, August). Praktik Bullying dalam Masa Orientasi Peserta Didik Baru dan Upaya Pemerintah Mengatasinya. Info Singkat Kesejahteraan Sosial, VII(15), 9-12.

Zakiyah, E. Z., Humaedi, S., \& Santoso, M. B. (2017). Faktor yang Mempengaruhi Remaja dalam Melakukan Bullying. Jurna Penelitian \& PPM, 4(2), 324-330. 